\title{
The Effect of Extrusion Voltage and Flowrate to the Viability and Survivability of Probiotic L. casei Encapsulated in Alginate-Chitosan
}

\author{
Djaenudin $^{1,2 *}$, Endang Saepudin ${ }^{2}$, and Muhamad Nasir ${ }^{1}$ \\ ${ }^{1}$ Research Unit For Clean Technology, Indonesian Institute of Sciences \\ Indonesia \\ ${ }^{2}$ Department of Chemistry, University of Indonesia \\ Indonesia \\ ${ }^{*}$ Corresponding author's email: aburizki [AT] yahoo.com
}

\begin{abstract}
Chitosan-coated L. casei containing alginate capsules (shortened as L. casei capsules) were prepared by extruding $L$. casei containing alginate solution at different extrusion voltage and and flow rate followed by coating the wet capsules in chitosan solution. This study aimed to determine the effect of extrusion voltage and sodium alginate liquid flow rate on the viability of $L$. casei bacteria in the encapsulation process. The encapsulation process in this study was carried out by the extrusion method using sodium alginate of $1 \%(w / v)$ and chitosan of $0.2 \%$ $(w / v)$. The resulted beads were immersed in a simulated gastric fluid (SGF) ( $\mathrm{NaCl} \mathrm{0.2 \% ;} \mathrm{HCl} 0.5 \mathrm{M}$ with a pH of 1.5) for 1, 60, and 120 min at $37^{\circ} \mathrm{C}$. The number of L. casei cells before encapsulation was $12.3 \log \mathrm{CFU}$. After encapsulation, the maximum viability of $L$. Casei obtained by voltage variations of $0 \mathrm{kV}$ and flow rate $5 \mathrm{~mL} / \mathrm{min}$ were 12.26 $\log$ CFU. After testing the beads in SGF for 1 min, the results obtained indicate that viability of L.casei in the sodium alginate - chitosan beads with an extrusion voltage of $0 \mathrm{kV}$ and $5 \mathrm{~mL} / \mathrm{min}$ was $11.8 \mathrm{log} \mathrm{CFU} / \mathrm{g}$. The result indicated that encapsulated $L$. casei in the sodium alginate - chitosan beads with a voltage of $0 \mathrm{kV}$ and $5 \mathrm{~mL} / \mathrm{min}$ was the highest survivability level of $97.38 \%$. The conclusions of the study were The higher extrusion voltage can kill more L. casei while the higher extrusion flow rate can protect more $L$. casei.
\end{abstract}

Keywords--- Encapsulation, probiotic, L.casei, na-alginate, chitosan, extrusion

\section{INTRODUCTION}

The term probiotic defined as living microorganisms which upon ingestion in certain numbers exert health benefits beyond inherent general nutrition [1]. Their health effects are due to the nutritional and therapeutic benefits, especially protection against harmful microorganisms and the improvement of the immune system [2]. Modulation of the endogenous flora and osmotic changed in the gastrointestinal tract are prebiotics mechanisms of action. The world consumption of probiotic foods has grown greatly in recent times. Probiotic bacteria were mainly incorporated into dairy products such as ice cream, frozen desserts products, cheese, fermented milk, milk powder, and yogurt [3-5]. However, with an increase in consumer vegetarianism throughout the developed countries, there was an increasing demand for vegetarian probiotic products (non-dairy probiotic products) [3]. To show their health benefits, the probiotic bacteria must survive during gastrointestinal transition [4].

Encapsulation of probiotics in hydrocolloid beads, was an appropriate procedure to protect the bacterial cells from the damages caused by the external environment in food products and during gastrointestinal transition. Several studies have reported the probiotic microencapsulation by using alginate and chitosan to provide protection to Bifidobacteria and Lactobacilli [7-10]. Among the encapsulating materials, alginate was the most commonly used polymer for encapsulating viable cells [7]. It consist of L-gulucoronic acid and D-mannuronic acid. Alginate can form beads with calcium chloride to encapsulate probiotic bacteria that was susceptible to acidic environments but alginate beads was porous, so that acidic fluid can enter the inside of alginate beads and killed probiotics[8]. Polycations, such as chitosan or polyamine acids can reduce the porosity of the alginate beads [6]. Chitosan is a natural, non-toxic and inexpensive linear polysaccharide with positive charge at low $\mathrm{pH}$, which has been used for coating the alginate beads. Low concentration chitosan solution $\left(2-4 \mathrm{~g} / \mathrm{m}^{3}\right)$ has been applied for shell-making on alginate and gelatin capsules $[8,11,12]$. Extrusion is one of the ancient and usual method to produce hydrocolloid capsules using a simple and low cost procedure that makes minimal injuries to probiotic cells while maintaining comparatively higher viability [11]. The hydrocolloid solution is mixed with microorganisms and mixture is delivered through an extruder (syringe) in a droplet form into hardening solution (calcium chloride) that consists of multivalent cations. After dripping, the cells are immediately entrapped by the polymers leading to three-dimensional lattices that cross links with calcium ions [8]. Mostly, alginate and calcium chloride concentration ranges from $0.5 \%$ to $4 \%$ and $0.05-1.5 \mathrm{M}$, respectively. The beads 
size ranges from 2 to $3 \mathrm{~mm}$ in diameter which mostly depended upon the distance between the syringe and hardening solution, polymer type, viscosity, concentration, extrusion voltage, extrusion flow rate, and diameter of the extruder[12]. The aim of this study was to determine the effect of extrusion voltage and sodium alginate flow rate on the viability of Lactobacillus casei (L. casei) in the encapsulation process.

\section{Equipments}

\section{EXPERIMENTAL SECTION}

Ose needles, measuring flask (Pyrex), petri dishes (Normax), beaker glass (Pyrex), Erlenmeyer, funnels, test tubes, spatulas, volume pipettes, micropipettes (Effendorf), stirring rods, $\mathrm{pH}$ meter (Horiba, Japan), filter paper Whatman no. 40, watch glass, autoclaves (Tomy SX- 300), shaker incubator (CERTOMAT® BS-1), incubator (Memmert 854 Schwabach), vortex (Thermo), refrigerators, aluminum foil, plastic wrap, analytical balance, glass preparations, microscopes, hot plates, magnetic stirrers, Scanning Electron Microscopy (SEM) (JEOL JSM-IT300), Laminar Air Flow (ETL), syringe (Therumo) 22 G (inner diameter $0.394 \mathrm{~mm}$ ), syringe $60 \mathrm{~mL}$.

\section{Materials}

The chemicals used were chitosan 0.2\% (Sigma Aldrich PCode: 101729402), MRSA (de Man Rogosa Sharpe Agar) and MRSB (de Man Rogosa Sharpe Broth) (Merck, KGaA), Na-alginate 1\% (HIMEDIA® REF MB-114-100G), $\mathrm{NaCl} 0.2 \% \mathrm{pH} 1.5, \mathrm{CaCl}_{2}$ Solution $32 \mathrm{~g} / \mathrm{L}$, Na-Citrate $1 \%$.

\section{Procedure}

\section{Preparation of Sodium Alginate Solution Containing Bacterial Suspension}

Preparation of sodium alginate solution was made from an alginate solution $40 \mathrm{~mL}$ with a concentration of $1 \%$ (w/v) with distilled water. At that point sterilized via autoclaving at $121^{\circ} \mathrm{C}$ for $15 \mathrm{~min}$. After the water has been cooled to room temperature, then $10 \mathrm{~mL}$ L. casei suspension was included.

\section{Preparation of Chitosan Solution}

The chitosan solution was made with a concentration of chitosan $0.2 \%(\mathrm{w} / \mathrm{v})$. Chitosan was dissolved in a $1 \%$ (v/v) acetic acid solution; then, the solution was sterilized by autoclaving at $121{ }^{\circ} \mathrm{C}$ for $15 \mathrm{~min}$.

\section{Surface morphology and bead size determination}

The shape and surface characteristics were determined by scanning electron microscopy (SEM) using a gold sputter technique. The microcapsules were vacuum-dried, coated with gold-palladium, and observed microscopically. The size of the L. casei loaded microcapsules was measured with SEM.

\section{Survival of L. casei loaded in microcapsules}

To determine the viable counts of the encapsulated L. casei, $1 \mathrm{~g}$ of capsules were resuspended in 9 $\mathrm{mL}$ of sodium citrate $(1 \%)$ and stirred for $120 \mathrm{~min}$ using a magnetic stirrer. The complete release of bacteria from the microcapsules in 120 min was previously assured by comparing the released number of cells from the capsules. The colony-forming units (CFU/g) were determined by anaerobic plating on MRS agar plate and incubating at $37{ }^{\circ} \mathrm{C}$ for $48 \mathrm{~h}$. The plating procedures were carried out in triplicates. Nonencapsulated $L$. casei was enumerated in the MRS agar as control.

\section{Encapsulation of L. casei Using Sodium Alginate-Chitosan Mixture}

The L. casei probiotic encapsulation method chosen was the extrusion method and the ionic gelation method. The extrusion method was chosen because besides using a simple tool in the form of a syringe, this method was also chosen to avoid extreme temperatures and pressures and from unfavorable environments such as low temperatures in the freezedrying method, which can result in reduced bacterial viability [13]. While the choice of ionic gelation method was due to a simple process, did not use organic solvents, and can be controlled easily. While the principle of particle formation in the ionic gelation method was the occurrence of ionic interactions between the divalent cation $\left(\mathrm{Ca}^{+2}\right)$ and the carboxylic anion $\left(\mathrm{COO}^{-}\right)$of the alginate monomer. Cross-linking occurs because a calcium ion replaced two sodium ions in alginate. This crosslinking structure caused limited molecular motion and inhibited the development of polymers in a medium [14]. The extrusion technique of microencapsulation was used [15]. Alginate microcapsules were prepared as follows: sodium alginate was dissolved in distilled water $(1 \%, \mathrm{w} / \mathrm{v})$ and sterilized at $121^{\circ} \mathrm{C}$ for 15 min. After cooling the alginate mixture, the cell suspension $(10 \mathrm{~mL})$ was mixed with the alginate mixture $(40$ $\mathrm{mL})$ homogeneously and injected through a syringe into sterilized $125 \mathrm{~mL} \mathrm{CaCl} 2(32 \mathrm{~g} / \mathrm{L})$ solution that was stirred continuously to form capsules. The capsules were allowed to harden for about $30 \mathrm{~min}$ in the $\mathrm{CaCl}_{2}$ solution and then washed with the distilled water. The beads were dried under controlled air flow and temperature $\left(4^{\circ} \mathrm{C}\right)$. Alginate-chitosan microcapsules were prepared as follows: the wet state of alginate coated beads was immersed in $50 \mathrm{~mL}$ of chitosan solution $(0,2 \%, \mathrm{w} / \mathrm{v})$ and stirred for $15 \mathrm{~min}$ using a magnetic stirrer.

The beads were dried under controlled air flow and temperature $\left(4^{\circ} \mathrm{C}\right)[16]$. 


\section{Viability and Survivability Testing of L. casei probiotic}

Simulation gastric fluid (SGF) consisted of $0.2 \%$ Sodium chloride with a $\mathrm{pH}$ of 1.5 (adjusting the pH by adding $0.5 \mathrm{M}$ hydrochloric acid). $1 \mathrm{~g}$ capsule (extrusion flow rate of 1,3 , and $5 \mathrm{~mL} / \mathrm{min}$ with extruder voltage of 0,10 , and 20 kiloVolt $(\mathrm{kV})$ ) were immersed in $9 \mathrm{~mL}$ SGF, incubated for 1,60 , and $120 \mathrm{~min}$ at a temperature of $37^{\circ} \mathrm{C}$. After that, it was filtered using Wattman 40 filter paper then immersed in $9 \mathrm{~mL}(1 \mathrm{~g} / 100 \mathrm{~mL})$ sterile sodium citrate solution with slow stirring at room temperature. Then sequential dilution was prepared to reach the number of cells that can be calculated by pouring a suspension technique that was spread on MRS Agar media. After that, it was incubated for 48 hours at 37 ${ }^{\circ} \mathrm{C}$ [17]. The total colony can be calculated by the Total Plate Count (TPC) method.

\section{RESULTS AND DISCUSSION}

Encapsulation probiotic $L$. casei

The result of making encapsulation with sodium alginate: chitosan (1\%: $0.2 \%)$ with a flow rate of $5 \mathrm{~mL} / \mathrm{min}$ and voltages of 0,10 , and $20 \mathrm{kV}$ showed in figure 1.a.

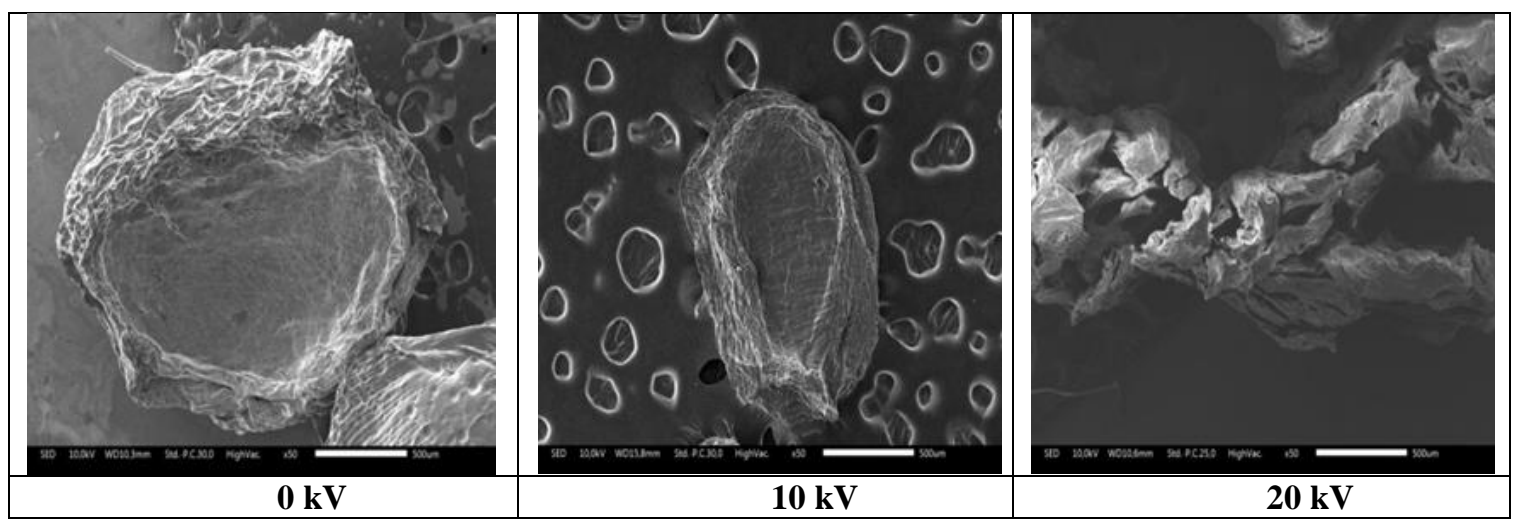

Figure 1. a. Encapsulated beads on various voltage variations.

The extruded electric voltage of $0 \mathrm{kV}$ produces a capsule size of $1000 \mu \mathrm{m}-1,100 \mu \mathrm{m}$. The extruded $10 \mathrm{kV}$ voltage produces a capsule size of $500 \mu \mathrm{m}-1000 \mu \mathrm{m}$. Extruded $20 \mathrm{kV}$ voltage produces capsules of $100 \mu \mathrm{m}-200 \mu \mathrm{m}$, and the capsules tend to be damaged. Figure 1.a showed that the higher extrusion voltage resulted in the smaller size of the beads. This happened because of high voltage can create a high electrostatic force so that the liquid in the extruder was pulled to the bottom faster and even bursts. The result of making encapsulation with sodium alginate: chitosan (1\%: $0.2 \%$ ) with a voltage of $0 \mathrm{kV}$ and flow rates of 1,3 , and $5 \mathrm{~mL} / \mathrm{min}$ showed in figure 1.b.

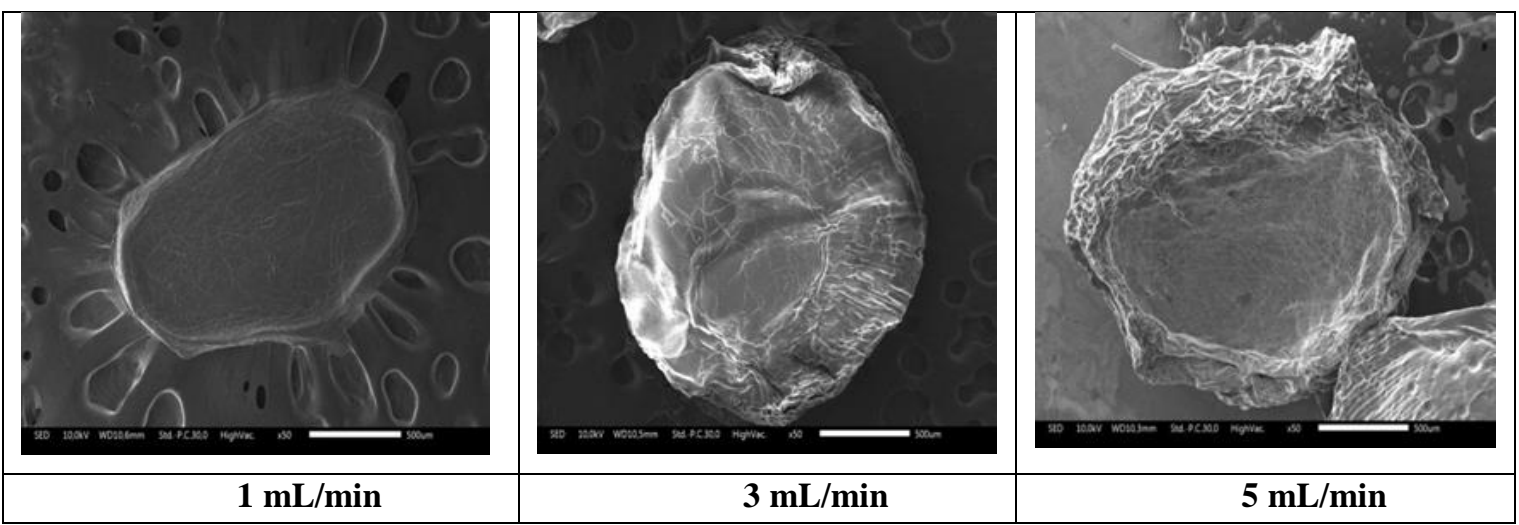

Figure 1. b. Encapsulated beads on various flow rate variations.

Figure 1.b showed that the higher flow rate resulted in the bigger size of the beads. The extrusion flow rate of 1 $\mathrm{mL} / \mathrm{min}$ produces a capsule size of $600 \mu \mathrm{m}-800 \mu \mathrm{m}$. The extrusion flow rate of $3 \mathrm{~mL} / \mathrm{min}$ produces a capsule size of $750 \mu \mathrm{m}-1000 \mu \mathrm{m}$. The extrusion flow rate of $5 \mathrm{~mL} / \mathrm{min}$ produces a capsule size of 1,100 $\mu \mathrm{m}-1,200 \mu \mathrm{m}$. A higher extrusion rate resulted in a higher amount of the encapsulating material forming a larger bead size than at a lower extrusion rate.

\section{Test of viability and yield of probiotic $L$. casei encapsulation process in sodium citrate solution}


The newly encapsulated particles $(1 \mathrm{~g})$, soaked in $9 \mathrm{~mL}(1 \mathrm{~g} / 100 \mathrm{~mL})$ sterile sodium citrate solution with slow stirring at room temperature. Then sequential dilution was prepared to reach the number of cells that can be calculated by pouring plates in MRS Agar.

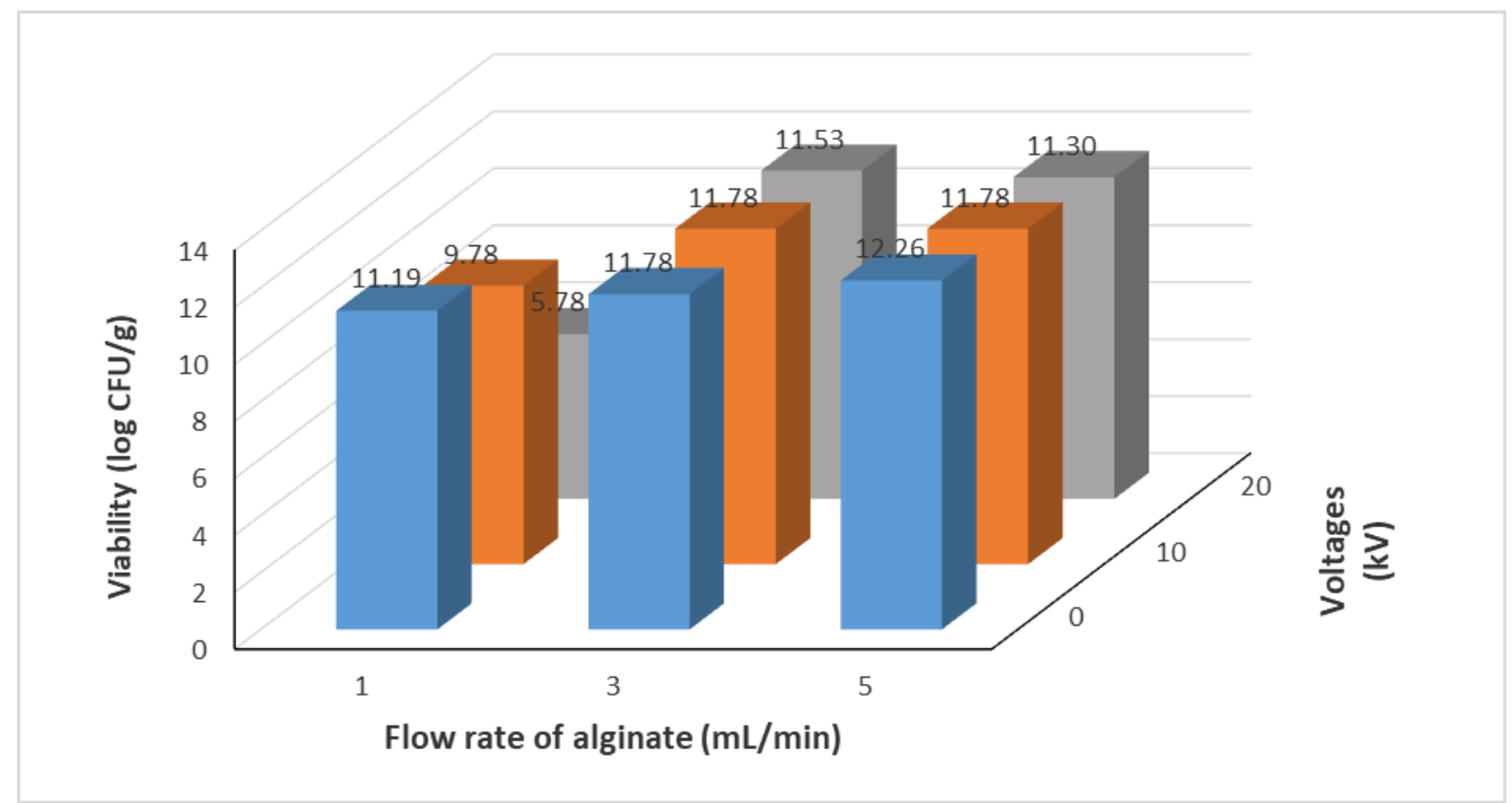

Figure 2. Viability of L. casei on various voltage variations and flow rate of extrusion.

The number of $L$. casei cells before encapsulation was $12.3 \log \mathrm{CFU}\left(2 \times 10^{12} \mathrm{CFU}\right)$. After encapsulation, the maximum viability of $L$. casei was $12.26 \log \mathrm{CFU}\left(1.8 \times 10^{12} \mathrm{CFU}\right.$ ) (Figure 2) was obtained for the variation of 5 $\mathrm{mL} / \mathrm{min}$ flow rate and the $0 \mathrm{kV}$ extrusion voltages. The higher voltage can decrease probiotics viability while the greater flow rate of alginate can protect probiotics viability. While the level of yield was shown in Figure 3 below.
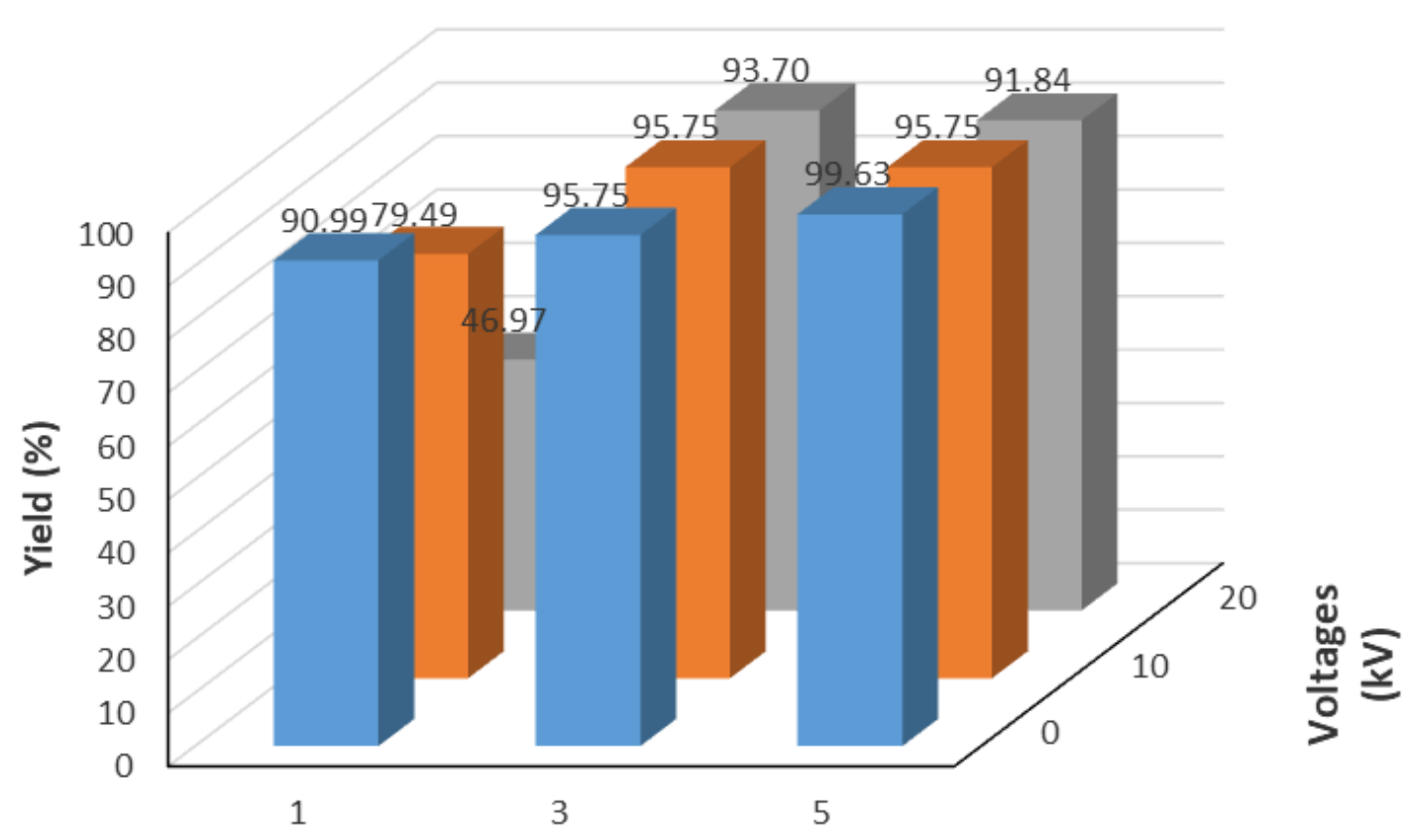

\section{Flow rate of alginate $(\mathrm{mL} / \mathrm{min})$}

Figure 3. L. casei yield on various voltage variations and flow rate of extrusion. 
Figure 3 above showed that the highest L. casei yield of $99.63 \%$ was obtained for the variation of $5 \mathrm{~mL} / \mathrm{min}$ flow rate and the $0 \mathrm{kV}$ extrusion voltage. While on the high voltage, the yield of $L$. casei decreased. This result showed that $L$. casei could not withstand high voltages.

\section{Viability and survivability test of L. casei in simulation gastric fluid (not encapsulated cells)}

The results of the L. casei probiotic Total Plate Count (TPC) test in broth liquid had a viability of $2 \times 10^{11}$ CFU/mL. L. casei preparations, which had a viability of $2 \times 10^{11} \mathrm{CFU} / \mathrm{mL}$, were immersed in a simulated gastric fluid solution containing $0.2 \% \mathrm{NaCl}$ solution $\mathrm{pH} 1.5$ at various variations of immersion time, i.e., 1, 60, and $120 \mathrm{~min}$. The result of the calculation of the Total Plate Count (TPC) of the probiotic L. casei showed the viability of 0 CFU/mL for 1 min. This result meant that $L$. casei, which was not encapsulated, will experience direct death once immersed in simulation gastric fluid $\mathrm{pH} 1.5$, or in other words, the survivability was $0 \%$.

\section{Test the viability and survivability of L. casei in simulation gastric fluid (encapsulated cells)}

A $0.5 \mathrm{~mm}$-sized bead shape produced by L. casei probiotic, which was encapsulated with the alginate-chitosan matrix through an extrusion method. Then the beads are immersed in a simulation gastric fluid containing $0.2 \% \mathrm{NaCl}$ solution with a pH of 1.5 and varying incubation time from $1 \mathrm{~min}, 60 \mathrm{~min}$ and $120 \mathrm{~min}$. When the beads were immersed in the liquid, they shrink in size. After the beads were immersed, they were removed and dried. Then the beads were immersed in sodium citrate $\mathrm{pH}$ 8. As a result of immersion in the sodium citrate solution, the beads swell, so the probiotics trapped in the beads can come out. Then the probiotic viability was tested using the TPC method. The test results were shown in Figure 4, 5, and 6 below.



Figure 4. Viability (left) and survivability (right) of encapsulated L. casei in SGF immersion pH 1,5 for $1 \mathrm{~min}$.

The viability of L.casei from beads immersed in SGF pH 1.5 for 1 min did not show a significant decrease except for the encapsulated beads with an extrusion flow rate of $1 \mathrm{~mL} / \mathrm{min}$. This happened because the beads formed by the encapsulation process with a flow rate of $1 \mathrm{~mL} / \mathrm{min}$ produced small beads so that SGF easily killed L.casei in the beads (as shown in Figure 1.b.). Figure 4 above showed that the highest $L$. casei viability of $11.8 \log \mathrm{CFU} / \mathrm{g}\left(1.5 \mathrm{x} 10^{11}\right.$ $\mathrm{CFU} / \mathrm{g}$ ) (survivability of $97.38 \%$ ) was obtained for the variation of the $0 \mathrm{kV}$ voltage and $5 \mathrm{ml} / \mathrm{minute}$ flow rate. Whereas at the voltage of $20 \mathrm{kV}$ and $1 \mathrm{~mL} / \mathrm{min}$ flow rate, the viability value was $0 \mathrm{CFU} / \mathrm{g}$ (survivability of $0 \%$ ).


Figure 5. Viability (left) and survivability (right) of encapsulated L. casei in SGF immersion pH 1,5 for $60 \mathrm{~min}$.

Figure 5 above showed that the highest $L$. casei viability of $9.06 \log$ CFU/g $\left(1.15 \times 10^{9} \mathrm{CFU} / \mathrm{g}\right.$ ) (survivability of 78.95 $\%$ ) was obtained for the variation of the $0 \mathrm{kV}$ voltage and $5 \mathrm{~mL} / \mathrm{min}$ flow rate. Whereas at the voltages of 10 , and $20 \mathrm{kV}$ 
and 1,3 , and $5 \mathrm{~mL} / \mathrm{min}$ flow rates, the viability value was $0 \mathrm{CFU} / \mathrm{g}$ (survivability of $0 \%$ ). This happened because the beads formed from the extrusion process with a voltage of 10 , and $20 \mathrm{kV}$ tended to be small and damaged (as shown in Figure 1.a.) so that SGF easily made contact with L. casei in these beads that they were killed so easily.



Figure 6. Viability (left) and survivability (right) of encapsulated L. casei in SGF immersion pH 1,5 for 120 min.

Figure 6 above showed that the viability of L. casei was $0 \mathrm{CFU} / \mathrm{g}$ (survivability of $0 \%$ ) for all experiment variations when beads were immersed for $120 \mathrm{~min}$ in simulation gastric fluid $\mathrm{pH} 1.5$. This happened because for 120 min the chitosan that filled the pores dissolved completely in SGF so that SGF can enter the alginate pores which resulted in SGF came into contact with L. casei and killed it[18-20].

\section{CONCLUSION}

The number of $L$. casei cells before encapsulation was $12.3 \log$ CFU. After encapsulation, the maximum viability of $L$. casei obtained by voltage variations of $0 \mathrm{kV}$ and flow rate $5 \mathrm{~mL} / \mathrm{min}$ were $12.26 \log \mathrm{CFU}$. Encapsulated $L$. casei immersed in SGF pH 1.5 for 1 minute resulted in the highest $L$. casei viability of $11.8 \mathrm{log}$ CFU/g (survivability of 97.38 $\%$ ) obtained for $0 \mathrm{kV}$ voltage and $5 \mathrm{~mL} / \mathrm{min}$ flow rate. Whereas at the voltage of $20 \mathrm{kV}$ and extrusion flow rate of 1 $\mathrm{mL} / \mathrm{min}$, the viability value was $0 \mathrm{CFU} / \mathrm{g}$ (survivability of $0 \%$ ). Encapsulated L. casei immersed in SGF pH 1.5 for 60 min resulted in the highest $L$. casei viability of $9.06 \log$ CFU/g (survivability of $78.95 \%$ ) obtained for $0 \mathrm{kV}$ voltage and extrusion flow rate of $5 \mathrm{~mL} / \mathrm{min}$. Whereas at the voltages of 10 and $20 \mathrm{kV}$ and extrusion flow rates of 1,3 , and 5 $\mathrm{mL} / \mathrm{min}$, the viability value was $0 \mathrm{CFU} / \mathrm{g}$ (survivability of $0 \%$ ). On the encapsulation process, the higher extrusion voltage can kill more L. casei while the higher extrusion flow rate can protect more $L$. casei.

\section{REFERENCES}

[1] J. Fao, W. H. O. Working, G. Report, D. Guidelines, and F. London, 2002, Guidelines for the Evaluation of Probiotics in Food.

[2] C. R. Soccol et al., 2010, The potential of probiotics: A review, Food Technol. Biotechnol., 48 (4), $413-434$.

[3] R. D. C. S. Ranadheera, S. K. Baines, and M. C. Adams, 2010, Importance of food in probiotic efficacy, Food Research International, 43 (1), 1-7, doi: 10.1016/j.foodres.2009.09.009.

[4] F. C. Prado, J. L. Parada, A. Pandey, and C. R. Soccol, 2008, Trends in non-dairy probiotic beverages, Food Res. Int., 41 (2), 111-123, doi: 10.1016/j.foodres.2007.10.010.

[5] S. Soodbakhsh, H. R. Gheisari, M. Aminlari, and T. Dehnavi, 2012, Viability of encapsulated Lactobacillus casei and Bifidobacterium Lactis in synbiotic frozen yoghurt and their survival under in vitro simulated gastrointestinal conditions, Int. J. Probiotics Prebiotics, 7 (3), 2012.

[6] F. Ortakci and S. Sert, 2012, Stability of free and encapsulated Lactobacillus acidophilus ATCC 4356 in yogurt and in an artificial human gastric digestion system, J. Dairy Sci., 95 (12), 6918-6925, doi: 10.3168/jds.20125710.

[7] S. Abbaszadeh, H. Gandomi, A. Misaghi, S. Bokaei, and N. Noori, 2014, The effect of alginate and chitosan concentrations on some properties of chitosan-coated alginate beads and survivability of encapsulated Lactobacillus rhamnosus in simulated gastrointestinal conditions and during heat processing, J. Sci. Food Agric., 94 (11), 2210-2216, doi: 10.1002/jsfa.6541.

[8] W. Krasaekoopt, B. Bhandari, and H. Deeth, 2004, The influence of coating materials on some properties of alginate beads and survivability of microencapsulated probiotic bacteria, Int. Dairy J., 14, 737-743, doi: 
10.1016/j.idairyj.2004.01.004.

[9] G. Orive et al., 2003, Cell encapsulation: promise and progress, Nature Medicine, 9 (1), 104-107, doi: 10.1038/nm0103-104.

[10] S. Gouin, 2004, Microencapsulation: Industrial appraisal of existing technologies and trends, Trends Food Sci. Technol., 15 (7-8), 330-347, doi: 10.1016/j.tifs.2003.10.005.

[11] A.M. Mortazavian et al., 2008, Survival of encapsulated probiotic bacteria in Iranian yogurt drink ( Doogh ) after the product exposure to simulated gastrointestinal conditions, Probiotic Bact. Doogh, 63 (4), 349-472.

[12] H. K. Solanki et al., 2013, Development of microencapsulation delivery system for long-term preservation of probiotics as biotherapeutics agent, Biomed Res. Int., 2013, 1-21, doi: https://doi.org/10.1155/2013/620719.

[13] C. Desmond, C. Stanton, G. F. Fitzgerald, K. Collins, and R. Paul Ross, 2002, Environmental adaptation of probiotic lactobacilli towards improvement of performance during spray drying, Int. Dairy J., 12 (2-3), 183190, doi: 10.1016/S0958-6946(02)00040-7.

[14] E. Mardliyati, S. El Muttaqien, and D. R. Setyawati, 2012, Sintesis nanopartikel kitosan- trypoly phosphate dengan metode gelasi ionik: pengaruh konsentrasi dan rasio volume terhadap karakteristik partikel, Pros. Pertem. Ilm. Ilmu Pengetah. dan Teknol. Bahan, 90-93.

[15] W. Krasaekoopt, B. Bhandari, and H. Deeth, 2003, Evaluation of encapsulation techniques of probiotics for yoghurt, Int. Dairy J., 13 (1), 3-13, doi: 10.1016/S0958-6946(02)00155-3.

[16] J. Burgain, C. Gaiani, M. Linder, and J. Scher, 2011, Encapsulation of probiotic living cells: From laboratory scale to industrial applications, J. Food Eng., 104 (4), 467-483, doi: 10.1016/j.jfoodeng.2010.12.031.

[17] S. Woraharn, C. Chaiyasut, B. Sirithunyalug, and J. Sirithunyalug, 2010, Survival enhancement of probiotic Lactobacillus plantarum CMU-FP002 by granulation and encapsulation techniques, African J. Microbiol. Res., 4 ( 20), 2086-2093.

[18] M. Ali, K. Zanjani, and B. Ghiassi, 2014, Microencapsulation of probiotics by calcium alginate-gelatinized starch with chitosan coating and evaluation of survival in simulated human gastro-intestinal condition, Iran. J. Pharm. Res., 13 (3), 843-852.

[19] S. Nualkaekul, D. Lenton, M. T. Cook, V. V. Khutoryanskiy, and D. Charalampopoulos, 2012, Chitosan coated alginate beads for the survival of microencapsulated Lactobacillus plantarum in pomegranate juice, Carbohydr. Polym., 90 (3), 1281-1287, doi: https://doi.org/10.1016/j.carbpol.2012.06.073.

[20] M. T. Cook, G. Tzortzis, V. V Khutoryanskiy, and D. Charalampopoulos, 2013, chitosan - alginate for the improved survival and administration $\dagger$, J. Mater. Chem. B, 1, 52-60, doi: https://doi.org/10.1039/c2tb00126h. 